\title{
PENGARUH GAJI, BONUS, DAN FASILITAS TERHADAP MOTIVASI KERJA KARYAWAN PADA PT. BANK SULSELBAR KANTOR PUSAT MAKASSAR
}

\author{
Maryadi $^{1}$
}

Stie Nobel Makassar

\begin{abstract}
Abstrak
Penelitian ini bertujuan untuk mengetahui dan menganalisis pengaruh gaji, bonus, fasilitas terhadap motivasi kerja karyawan pada PT. Bank Sulselbar Kantor Pusat Makassar. Pada penelitian ini yang menjadi populasi adalah seluruh karyawan pada PT. Bank Sulselbar Kantor Pusat Makassar. Untuk kantor pusat PT. Bank Sulselbar memiliki 189 karyawan yang terbagi atas 175 pegawai organik dan 14 pegawai kontrak. Metode pengambilan sampel yang digunakan dalam penelitian ini adalah Metode Slovin. Metode pengumpulan data dilakukan dengan wawancara, koesioner, dan studi dokumentasi. Sumber data penelitian ini yaitu data primer dan data sekunder. Metode analisis data dengan menggunakan SPSS, Multiple Linear Regression/Regresi Linear Berganda, uji validitas, uji reliabilitas dan uji Hipotesis.

Hasil penelitian menunjukkan bahwa (1) Gaji mempunyai pengaruh yang positif namun tidak signifikan terhadap motivasi kerja karyawan. Hal tersebut dilihat dari tanggapan responden bahwa masih ada bebarapa responden yang masih belum puas dengan gaji yang didapatkan dan berharap gaji yang diberikan bisa dinaikkan lagi untuk mencukupi kebutuhan mereka sehingga dapat meningkatkan motivasi mereka dalam bekerja, (2) Bonus mempunyai pengaruh yang positif dan signifikan terhadap motivasi kerja karyawan. Hal tersebut dilihat dari tanggapan responden bahwa dengan adanya tambahan bonus yang diberikan mereka dapat memiliki motivasi kerja yang tinggi. Dengan begitu kebutuhan mereka tercukupi dengan adanya tambahan bonus diluar gaji yang telah diberikan, (3) Fasilitas mempunyai pengaruh yang positif dan signifikan terhadap motivasi kerja karyawan. Hal tersebut dilihat dari tanggapan responden bahwa dengan adanya fasilitas yang nyaman dalam bekerja maka mereka dapat memiliki motivasi kerja yang tinggi.
\end{abstract}

\section{Pendahuluan}

Perkembangan dunia perbankan akhir-akhir ini mengalami suatu kemajuan yang cukup pesat. Sejak adanya paket-paket kebijakan yang dikeluarkan pemerintah dan adanya UU No. 10 Tahun 1998 tentang perbankan telah terjadi kemudahan-kemudahan untuk mencoba merangsang daya tumbuh dan daya saing antar bank di Indonesia. Persaingan terbuka yang semakin tajam memaksa setiap bank untuk mencari keunggulan diri dengan bank-bank lainnya, melalui produk-produk perbankan serta dengan memberikan fasilitas-fasilitas dan kemudahankemudahan bagi setiap nasabahnya. Hal ini menyebabkan masing-masing bank ingin mencoba menerapkan kebijaksanaan manajemen melalui profesionalisme di bidang perbankan.

Manajemen perbankan tidak akan mungkin lepas dari faktor kualitas Sumber Daya Manusia (SDM) yang merupakan faktor yang sangat fundamental dan strategis. Berbagai usaha dilakukan untuk peningkatan tenaga yang profesional bahkan penyediaan dana untuk meningkatkan kesejahteraan serta biaya pengembangan yang sangat besar, sehingga seolaholah efesiensi yang selama ini diterapkan di setiap perbankan menjadi alternatif yang kedua. 
Banyak ahli yang mengemukakan bahwa produktifitas suatu perusahaan banyak dipengaruhi oleh tenaga kerja yang ada, diantaranya menurut Wibowo (2007:244) yang mengatakan yaitu: "produktifitas merupakan ratio antara hasil (keluaran) terhadap masukan.

Keberhasilan Bank Sulselbar dalam menjalankan kegiatan bisnisnya selama tahun 2013 tidak lepas dari dukungan Sumber Daya Manusia (SDM) yang memadai untuk mengelola berbagai fungsi organisasi dan menghadapi berbagai tantangan. Bank Sulselbar secara konsisten dan berkesinambungan terus berupaya membentuk dan mengembangkan potensi human capital yang dimiliki karena perusahaan memandang bahwa SDM yang berkualitas merupakan aset penting bagi kelangsungan dan keberhasilan Bank Sulselbar di masa mendatang. Oleh karena itu, berbagai inisiatif telah dilakukan untuk menjaga kualitas SDM Bank Sulselbar agar sesuai dengan kebutuhan bisnis dengan cara yang efektif.

Sumber daya manusia sangat erat hubungannya dengan perbankan. Sumber daya manusia yang merupakan harta terpenting yang harus dimiliki perbankan adalah karyawan. Tanpa adanya para karyawan dalam perbankan tersebut, maka perbankan tidak akan bisa berkembang.

Antara perbankan dengan karyawan pun sebenarnya ada hubungan erat dimana perbankan dan karyawan tersebut ialah saling membutuhkan. Perbankan membutuhkan para karyawan untuk mencapai tujuan utamanya. Sedangkan karyawan membutuhkan perbankan untuk membantu memenuhi kebutuhannya sebagai makhluk hidup seperti kebutuhan tempat tinggal, kebutuhan makan, dan sebagainya.

Untuk itu, sudah sewajarnya bila suatu perbankan memberi balas jasa berupa bonus kepada karyawannya. Dan karyawan pun sudah seharusnya memberikan kemampuan kinerja terbaik terhadap perbankan tempat ia bekerja. bonus yang perbankan berikan haruslah sebanding dengan apa yang diberikan karyawan tersebut karena perbankan harus bisa bersikap adil kepada semua karyawannya. Sehingga para karyawan dapat memberikan prestasi terbaiknya untuk meningkatkan perbankan tersebut.

Bertitik tolak dari kebutuhan karyawan dalam mencapai prestasi kerja yang lebih tinggi dan mau bekerja dengan penuh dedikasi pada pekerjaan sesuai dengan objektif yang telah digariskan, maka perusahaan perlu memotivasi karyawan dengan menggunakan pendekatan pada karyawan itu sendiri. Sedangkan cara yang terbaik memotivasi karyawan dijelaskan dengan jalan usaha memenuhi kebutuhan dan keinginan karyawan di atas.

Di dalam memotivasi karyawan perusahaan juga mengetahui tentang prinsip dari motivasi, (Siswanto 2002: 268) yaitu: Suatu usaha positif dalam menggerakkan daya dan potensi agar secara produktifitas berhasil mencapai tujuan yang telah ditetapkan sebelumnya.

Gaji adalah suatu bentuk balas jasa atau biasa disebut dengan penghargaan yang diberikan secara teratur kepada seorang karyawan atas jasa dan hasil kerjanya yang biasa diberikan secara bulanan. Bonus dapat diartikan sebagai sejumlah uang yang ditambahkan ke gaji bagi para karyawan agar termotivasi untuk mencari keuntungan bagi keberhasilan ekonomi perusahaan. Sedangkan fasilitas adalah kenikmatan dalam bentuk nyata/natura yang diberikan perusahaan oleh karena hal-hal yang bersifat khusus atau untuk meningkatkan kesejahteraan karyawan.

Gaji, bonus, dan fasilitas ini diberikan dengan tujuan dapat menarik calon tenaga kerja yang berkualitas untuk bergabung dalam perbankan, mempertahankan karyawan yang memiliki kinerja yang sangat baik, juga untuk memotivasi para karyawannya.

Namun, fenomena yang ada masih terdapat beberapa karyawan di setiap perbankan yang telah disediakan bonus namun masih belum memiliki motivasi yang cukup tinggi dalam meningkatkan prestasi dalam pekerjaannya.

Untuk mengetahui lebih jauh tentang motivasi karyawan pada PT. Bank Sulselbar Kantor Pusat Makasssar dari bonus maka penulis meneliti dengan judul, "Pengaruh Gaji, Bonus, dan 


\section{Fasilitas terhadap Motivasi Kerja Karyawan pada PT. Bank Sulselbar Kantor Pusat Makassar".}

\section{Kajian Pustaka}

\section{Pengertian Gaji}

Menurut Rivai dalam Kadarisman (2012:316), gaji adalah balas jasa dalam bentuk uang yang diterima karyawan/pegawai sebagai konsekuensi dari statusnya sebagai seorang pegawai yang memberikan kontribusi dalam pencapaian tujuan perusahaan/organisasi.

Hasibuan (2002:118) menyatakan bahwa "Gaji adalah balas jasa yang dibayar secara periodik kepada karyawan tetap serta mempunyai jaminan yang pasti". Pendapat lain dikemukakan oleh Soemarso (2009:307), "Gaji adalah imbalan kepada pegawai yang diberikan atas tugas-tugas administrasi dan pimpinan yang jumlahnya biasanya tetap secara bulanan".

Dari beberapa pengertian diatas, dapat diambil kesimpulan bahwa gaji adalah salah satu kompensasi yang diberikan kepada karyawan untuk memenuhi kebutuhannya dan dapat dijadikan motivasi agar karyawan dapat memiliki kinerja yang baik dalam bekerja.

\section{Fungsi Penggajian}

Menurut Komaruddin (1995) fungsi gaji bukan hanya membantu manajer personalia dalam menentukan gaji yang adil dan layak saja, tetapi masih ada fungsi-fungsi yang lain, yaitu

a. Untuk menarik pekerja yang mempunyai kemampuan ke dalam organisasi.

b. Untuk mendorong pekerja agar menunjukkan prestasi yang tinggi.

c. Untuk memelihara prestasi pekerja selama periode yang panjang.

\section{Pengertian Bonus}

Bonus adalah imbalan yang diberikan kepada karyawan yang mampu bekerja sedemikian rupa sehingga tingkat produksi yang baku terlampaui (Siagian, 1995). Sedangkan menurut (Sarwoto, 1995:141-142) pemberian bonus dapat digunakan sebagai sarana untuk memotivasi karyawan.

Ruky (2001:185) mendefenisikan bonus sebagai: "Pemberian pendapatan tambahan bagi karyawan/pekerja yang hanya diberikan setahun sekali bila syarat-syarat tertentu dipenuhi.

Idealnya untuk bonus adalah merefleksikan kinerja dari team/kelompok atau perorangan. Sehingga besar sekali kemungkinan bahwa ada beberapa pekerja yang memperoleh bonus yang lebih besar dari pekerja yang lainnya atau bahkan sama sekali tidak mendapatkan bonus.

Didalam pemberian bonus kepada karyawan. Perbankan memberikan bonus setiap tahun dengan waktu yang tidak ditentukan, bisa di awal tahun, pertengahan, atau akhir tahun. Besarnya bonus yang ditetapkan adalah satu sampai dua kali gaji pokok karyawan. 


\section{Manfaat Bonus}

Pemberian bonus kepada karyawan ini dimaksudkan untuk meningkatkan produktifitas kerja dan semangat kerja karyawan. Pengertian bonus menurut Simamora (2004:522) adalah "Pembayaran sekaligus yang diberikan karena memenuhi sasaran kinerja", sedangkan menurut Sarwoto (1991:156), pengertian bonus adalah :

a. Uang dibayar sebagai balas atas hasil pekerjaan yang telah dilaksanakan apabila melebihi target.

b. Diberikan secara sekali terima tanpa sesuatu ikatan di masa yang akan datang.

c. Beberapa persen dari laba yang kemudian dibagikan kepada yang berhak menerima bonus.

Dengan adanya bonus, diharapkan karyawan akan memotivasi dirinya untuk selalu meningkatkan kinerja. Bonus tidak hanya membantu memperbaiki kepuasan karyawan ataupun memotivasi karyawan dalam bekerja, akan tetapi juga membantu perusahaan dalam mengendalikan biaya-biaya. Selain itu, program bonus lebih mudah dipertahankan karena tidak memerlukan banyak dokumentasi dan sangat fleksibel.

\section{Fasilitas}

Rupik (2015:9) menjelaskan bahwa "Fasilitas merupakan segala hal yang dapat memudahkan dan melancarkan pelaksanaan kegiatan, yang dapat memudahkan kegiatan berupa sarana dan prasarana. Kamus Besar Bahasa Indonesia (2008:389) dalam Rupik (2015:9), "Fasilitas adalah sarana melancarkan pelaksanaan fungsi”.

\section{Manfaat dan Tujuan}

Dengan adanya fasilitas, diharapkan karyawan akan memotivasi dirinya untuk selalu meningkatkan kinerja. Selain untuk meningkatkan semangat kerja karyawan, pemberian fasilitas juga diberikan guna kesejahteraan karyawan. Kesejahteraan karyawan tersebut dapat mempertahankan dan memperbaiki kondisi fisik dan mental karyawan. Hal itu tentunya akan menciptakan rasa aman dan tentram, semangat kerja, dedikasi, disiplin dan sikap loyal terhadap perbankan.

Tujuan dari pemberian fasilitas ini adalah untuk mempertahankan keberadaan karyawannya. Apalagi karyawan yang memiliki keahlian atau skill yang sangat berharga.

\section{Motivasi}

Menurut Hasibuan (2007:95), "Motivasi adalah pemberian daya penggerak yang menciptakan kegairahan kerja seseorang, agar mereka mau bekerja sama, bekerja efektif dan terintegrasi dengan segala daya upayanya untuk mencapai kepuasan." Harold Koontz dalam Hasibuan (2007:95) menyatakan, "Motivasi mengacu pada dorongan dan usaha untuk memuaskan kebutuhan atau suatu tujuan." Stephen P. Robbins dalam Hasibuan (2007:96) mendefinisikan, "Motivasi sebagai suatu kerelaan untuk berusaha seoptimal mungkin dalam pencapaian tujuan organisasi yang dipengaruhi oleh kemampuan usaha untuk memuaskan beberapa kebutuhan individu". "Motivasi adalah keadaan dalam pribadi seseorang yang mendorong keinginan individu untuk melakukan kegiatan-kegiatan tertentu guna mencapai tujuan" (Handoko, 2003:252). 


\section{MOTODE PENELITIAN}

Lokasi penelitian ini dilaksanakan pada PT. Bank Sulselbar Kantor Pusat Makassar Jln. Dr. Sam Ratulangi No. 16 Makassar. Adapun Waktu pelaksanaan penelitian dilakukan selama kurang lebih satu bulan pada bulan Desember 2016 - Januari 2017.

Pada penelitian ini yang menjadi populasi adalah seluruh karyawan pada PT. Bank Sulselbar Kantor Pusat Makassar. Untuk kantor pusat PT. Bank Sulselbar memiliki 189 karyawan yang terbagi atas 175 pegawai organik dan 14 pegawai kontrak. Metode pengambilan sampel yang digunakan dalam penelitian ini adalah Metode Slovin. Metode pengumpulan data dilakukan dengan wawancara, koesioner, dan studi dokumentasi. Sumber data penelitian ini yaitu data primer dan data sekunder. Metode analisis data dengan menggunakan SPSS, Multiple Linear Regression/Regresi Linear Berganda, uji validitas, uji reliabilitas dan uji Hipotesis.

Adapun defenisi operasional penelitian ini yaitu Gaji adalah sejumlah uang yang diberikan kepada karyawan setiap bulan untuk memenuhi kebutuhannya atas kerja yang sudah dilakukan, Bonus adalah sejumlah uang yang ditambahkan ke gaji karyawan, atas prestasiprestasi yang telah diberikan oleh karyawan kepada perusahaan, Fasilitas adalah sesuatu yang berupa benda yang dapat memberikan kenikmatan tambahan kepada karyawan dalam meningkatkan kinerjanya, Motivasi adalah suatu dorongan semangat kerja karyawan atau keinginan dari dalam diri seseorang, yang menimbulkan rangsangan untuk bertindak melakukan suatu tindakan yang menurut penilaiannya dapat memberi manfaat baginya agar keinginannya terpenuhi serta dapat meningkatkan prestasi dalam bekerja.

\section{Hasil Penelitian dan Pembahasan}

\section{Uji Validitas dan Reliabilitas}

Uji validitas digunakan untuk mengukur sah atau valid tidaknya suatu instrumen. Instrumen yang sahih memiliki validitas tinggi. Instrumen dikatakan sahih apabila mampu mengukur apa yang diinginkan, mampu mengungkapkan data dari variabel yang diteliti secara tepat, tinggi rendahnya instrumen menunjukkan sejauh mana data yang terkumpul tidak menyimpang dari gambaran variabel yang dimaksud. Hasil analisa validitas program SPSS 16.0 ditunjukkan dengan membandingkan $r$ hasil (hitung) dengan nilai 0,3 apabila $r$ hasil $>0,3$ maka butir atau variabel yang diteliti adalah valid. Hasil analisis validitas yang didistribusikan kepada 65 responden untuk tiap-tiap butir adalah sebagai berikut :

TABEL 4.1

HASIL UJI VALIDITAS

\begin{tabular}{|c|c|c|c|c|}
\hline Variabel & $\begin{array}{c}\text { Butir } \\
\text { Pernyataan }\end{array}$ & $\begin{array}{c}\text { Nilai R } \\
\text { Hitung }\end{array}$ & $\begin{array}{c}\text { Nilai } \\
\text { Batas }\end{array}$ & Status \\
\hline & $\mathrm{X} 1.1$ & 0,840 & 0,3 & Valid \\
& $\mathrm{X} 1.2$ & 0,860 & 0,3 & Valid \\
& $\mathrm{X} 1.3$ & 0,882 & 0,3 & Valid \\
Gaji & $\mathrm{X} 1.4$ & 0,856 & 0,3 & Valid \\
(X1) & $\mathrm{X} 1.5$ & 0,816 & 0,3 & Valid \\
& $\mathrm{X} 1.6$ & 0,864 & 0,3 & Valid \\
& $\mathrm{X} 1.7$ & 0,418 & 0,3 & Valid \\
& $\mathrm{X} 1.8$ & 0,364 & 0,3 & Valid \\
\hline
\end{tabular}




\begin{tabular}{|c|c|c|c|c|}
\hline & X2.1 & 0,652 & 0,3 & Valid \\
& X2.2 & 0,783 & 0,3 & Valid \\
& X2.3 & 0,697 & 0,3 & Valid \\
& X2.4 & 0,676 & 0,3 & Valid \\
Bonus & X2.5 & 0,686 & 0,3 & Valid \\
(X2) & X2.6 & 0,656 & 0,3 & Valid \\
& X2.7 & 0,836 & 0,3 & Valid \\
& X2.8 & 0,680 & 0,3 & Valid \\
& X2.9 & 0,719 & 0,3 & Valid \\
& X2.10 & 0,430 & 0,3 & Valid \\
\hline & X3.1 & 0,814 & 0,3 & Valid \\
& X3.2 & 0,832 & 0,3 & Valid \\
& X3.3 & 0,833 & 0,3 & Valid \\
Fasilitas & X3.4 & 0,653 & 0,3 & Valid \\
(X3) & X3.5 & 0,801 & 0,3 & Valid \\
& X3.6 & 0,662 & 0,3 & Valid \\
& X3.7 & 0,601 & 0,3 & Valid \\
& X3.8 & 0,748 & 0,3 & Valid \\
& X3.9 & 0,774 & 0,3 & Valid \\
\hline & Y.1 & 0,681 & 0,3 & Valid \\
& Y.2 & 0,607 & 0,3 & Valid \\
& Y.3 & 0,675 & 0,3 & Valid \\
Karyawan & Y.4 & 0,681 & 0,3 & Valid \\
(Y) & Y.5 & 0,823 & 0,3 & Valid \\
& Y.6 & 0,789 & 0,3 & Valid \\
& Y.7 & 0,833 & 0,3 & Valid \\
& Y.8 & 0,602 & 0,3 & Valid \\
& Y.9 & 0,514 & 0,3 & Valid \\
\hline
\end{tabular}

Sumber : Hasil pengolahan data, 2017

Berdasarkan tabel 4.1 diatas yaitu hasil uji validitas atas variabel penelitian, maka dapat dijelaskan bahwa untuk variabel gaji, bonus, dan fasilitas terhadap motivasi kerja karyawan, dengan jumlah butir pernyataan adalah 36 menunjukkan hasil yang valid (sah). Sebab semua butir pernyataan memiliki nilai di atas 0,3 . Sedangkan butirbutir pernyataan yang gugur dinyatakan tidak ada.

\section{Uji Reliabilitas}

Uji Reliabilitas merupakan uji kehandalan yang bertujuan untuk mengetahui seberapa jauh alat ukur dapat dipercaya. Hasil pengukuran harus reliabel dalam artian harus memiliki tingkat konsistensi dan kemantapan. Metode yang digunakan dalam analisis reliabilitas ini adalah metode Alpha-Cronbach. Nilai Alpha-Cronbach ( $\mathrm{r}$ alpha) program SPSS ditunjukkan oleh besarnya nilai alpha $(\alpha)$. Pengambilan keputusan reliabilitas suatu variabel ditentukan dengan membandingkan nilai $r$ alpha dengan nilai 0,6 apabila $r$ alpha $>0,6$ maka variabel yang diteliti adalah reliabel. Adapun hasil pengujian reliabilitas dalam penelitian ini dapat dilihat pada tabel 4.2 berikut ini : 
TABEL 4.2

HASIL UJI RELIABILITAS

\begin{tabular}{|l|c|c|c|}
\hline \multicolumn{1}{|c|}{ Variabel } & $\boldsymbol{\alpha}$ Hitung & $\begin{array}{c}\text { Nilai } \\
\text { Batas }\end{array}$ & Status \\
\hline Gaji & 0,885 & 0,6 & Reliabel \\
\hline Bonus & 0,845 & 0,6 & Reliabel \\
\hline Fasilitas & 0,900 & 0,6 & Reliabel \\
\hline Motivasi Kerja Karyawan & 0,864 & 0,6 & Reliabel \\
\hline
\end{tabular}

Sumber : Hasil pengolahan data, 2017

Berdasarkan data mengenai hasil uji reliabilitas pada tabel 4.2 menunjukkan bahwa semua variabel dinyatakan reliabel sebab memiliki nilai Alpha-Cronbach diatas 0,6.

\section{Uji Determinasi}

Analisis koefisien determinasi digunakan untuk menunjukkan proporsi variabel dependen yang dijelaskan oleh variabel independen. Koefisien determinasi $\left(\mathrm{R}^{2}\right)$ mampu memberikan informasi mengenai variasi nilai variabel dependen yang dapat dijelaskan oleh model regresi yang digunakan. Apabila $\mathrm{R}^{2}$ mendekati angka satu berarti terdapat hubungan yang kuat. Nilai $\mathrm{R}^{2}$ yang diperoleh dijelaskan pada tabel 4.3 berikut ini:

TABEL 4.3

\section{HASIL UJI KOEFISIEN DETERMINASI}

\begin{tabular}{|c|c|}
\hline $\mathbf{R}$ & R Square \\
\hline 0,866 & 0,749 \\
\hline
\end{tabular}

Sumber : Hasil pengolahan data, 2017

Dari tabel 4.3 diatas dapat terlihat bahwa besarnya nilai $\mathrm{R}$ adalah 0,866 yang berarti hubungan antara gaji, bonus, dan fasilitas mempunyai hubungan yang cukup kuat terhadap motivasi kerja karyawan karena nilai $\mathrm{R}$ adalah $86,6 \%$ atau mendekati 1 . Sedangkan $\mathrm{R}$ square $\left(\mathrm{R}^{2}\right)$ adalah 0,749 ini menunjukkan bahwa besarnya pengaruh gaji, bonus, dan fasilitas terhadap motivasi kerja karyawan adalah sebesar 74,9\% sedangkan sisanya sebesar $25,1 \%$ variasi proses motivasi kerja karyawan dipengaruhi oleh variabel lain diluar model ini yang tidak diteliti.

\section{Analisis Regresi Linear Berganda}

Untuk hasil pengujian hipotesis dengan menggunakan uji t dapat dilihat melalui tabel 4.4 berikut ini :

TABEL 4.4

HASIL OLAHAN DATA REGRESI ANTARA GAJI, BONUS, DAN FASILITAS

\begin{tabular}{|l|c|c|c|c|}
\hline Variabel Independen & $\begin{array}{c}\text { Koef } \\
\text { Regresi }\end{array}$ & t hitung & Sig & Keputusan \\
\hline Konstanta & 0,866 & 3,520 & 0,001 & Signifikan \\
\hline Gaji & 0,030 & 0,397 & 0,692 & Tidak signifikan \\
\hline Bonus & 0,467 & 6,379 & 0,000 & Signifikan \\
\hline Fasilitas & 0,302 & 4,058 & 0,000 & Signifikan \\
\hline
\end{tabular}

Sumber : Hasil pengolahan data, 2017 
Berdasarkan tabel 4.4 mengenai hasil olahan data regresi dengan menggunakan SPSS 16.0 maka akan disajikan persamaan regresi yaitu :

$$
\mathrm{Y}=0,866+0,030 \mathrm{X}_{1}+0,467 \mathrm{X}_{2}+0,302 \mathrm{X}_{3}
$$

Dari hasil persamaan regresi pada tabel 4.47, maka disajikan penjelasan dari persamaan regresi yaitu sebagai berikut :

$\alpha=0,866$ yang diartikan bahwa dengan adanya gaji, bonus, dan fasilitas maka akan dapat meningkatkan motivasi kerja karyawan.

$\mathrm{b}_{1}=0,030$ hal ini menunjukkan bahwa apabila tanggapan responden mengenai gaji ditingkatkan sebesar satu satuan maka akan mempengaruhi motivasi kerja karyawan sebesar $0,030 \%$.

$\mathrm{b}_{2}=0,467$ hal ini menunjukkan bahwa apabila tanggapan responden mengenai bonus ditingkatkan sebesar satu satuan maka akan mempengaruhi motivasi kerja karyawan sebesar $0,467 \%$.

$\mathrm{b}_{3}=0,302$ hal ini menunjukkan bahwa apabila tanggapan responden mengenai fasilitas ditingkatkan sebesar satu satuan maka akan mempengaruhi motivasi kerja karyawan sebesar $0,302 \%$.

Berdasarkan hasil uji regresi linear berganda diatas, maka diketahui bahwa variabel bonus yang memiliki pengaruh paling dominan terhadap motivasi kerja karyawan dimana diperoleh nilai sebesar 0,467 jauh lebih besar dari faktor fasilitas dan gaji.

\section{Uji Parsial (Uji t)}

Uji t yaitu suatu uji untuk mengetahui pengaruh masing-masing variabel yakni gaji, bonus, dan fasilitas terhadap motivasi kerja karyawan pada PT. Bank Sulselbar Kantor Pusat Makassar. Pengujian melalui uji t adalah dengan membandingkan probabilitas kesalahan $\mathrm{t}$ hitung dengan signifikansi yang dapat ditelorir $(\alpha=5 \%)$. Sedangkan derajat bebas pengujian adalah n-k.

Dimana :

$\mathrm{n}=$ banyaknya observasi

$\mathrm{k}$ = banyaknya variabel (bebas dan terikat)

Jadi, df $2=65-4=61$

Berdasarkan nilai t tabelnya dengan pengujian satu arah untuk alpha 5\% adalah 1,670 (dapat dilihat pada tabel lampiran).

Adapun dasar pengambilan keputusan berdasarkan nilai t, yaitu :

Bila $\mathrm{t}$ hitung $>\mathrm{t}$ tabel maka $\mathrm{H}_{0}$ ditolak dan $\mathrm{H}_{1}$ diterima

Bila t hitung $<\mathrm{t}$ tabel maka $\mathrm{H}_{0}$ diterima dan $\mathrm{H}_{1}$ ditolak

Berikut ini disajikan hasil uji signifikan dapat dilihat pada tabel 4.48 yaitu sebagai berikut : 
TABEL 4.5

HASIL ANALISIS SECARA PARSIAL

\begin{tabular}{|l|c|c|c|}
\hline Variabel Independen & t hitung & Sig & Keputusan \\
\hline Gaji & 0,397 & 0,692 & Tidak signifikan \\
\hline Bonus & 6,379 & 0,000 & Signifikan \\
\hline Fasilitas & 4,058 & 0,000 & Signifikan \\
\hline
\end{tabular}

Sumber : Hasil pengolahan data, 2017

Berdasarkan tabel 4.5 dapat dilihat hasil perhitungan diperoleh untuk :

1. Uji parsial untuk gaji $\left(\mathrm{X}_{1}\right)$

Uji hipotesis untuk variabel gaji $\left(\mathrm{X}_{1}\right)$ terhadap motivasi kerja karyawan dapat dilakukan dengan dasar pengambilan keputusan sebagai berikut :

a. $\mathrm{H}_{0}: \mathrm{b}_{1}=0$ (tidak ada pengaruh antara $\mathrm{X}_{1}$ terhadap $\mathrm{Y}$ ) $\mathrm{H}_{1}: \mathrm{b}_{1}>0$ (ada pengaruh antara $\mathrm{X}_{1}$ terhadap $\mathrm{Y}$ )

b. Level of convidence $=95 \%$ dengan probability kesalahan $\alpha=0,05$

c. Daerah kritis t tabel $=1,670$ t hitung $X_{1}=0,397$

Berdasarkan hasil uji regresi antara gaji dengan motivasi kerja karyawan, maka diperoleh nilai $t$ hitung $0,397<\mathrm{t}$ tabel 1,670. Dan nilai sig 0,692 >0,05 berarti tidak ada pengaruh yang signifikan antara gaji dengan motivasi kerja karyawan pada PT. Bank Sulselbar Kantor Pusat Makassar.

2. Uji parsial untuk bonus $\left(\mathrm{X}_{2}\right)$

Uji hipotesis untuk variabel bonus $\left(\mathrm{X}_{2}\right)$ terhadap motivasi kerja karyawan dapat dilakukan dengan dasar pengambilan keputusan sebagai berikut :

a. $\mathrm{H}_{0}: \mathrm{b}_{2}=0$ (tidak ada pengaruh antara $\mathrm{X}_{2}$ terhadap $\mathrm{Y}$ ) $\mathrm{H}_{1}: \mathrm{b}_{2}>0$ (ada pengaruh antara $\mathrm{X}_{2}$ terhadap $\mathrm{Y}$ )

b. Level of convidence $=95 \%$ dengan probability kesalahan $\alpha=0,05$

c. Daerah kritis t tabel $=1,670$ t hitung $X_{2}=6,379$

Berdasarkan hasil uji regresi antara bonus dengan motivasi kerja karyawan, maka diperoleh nilai t hitung 6,379 $>\mathrm{t}$ tabel 1,670. Dan nilai sig 0,000<0,05 berarti ada pengaruh yang signifikan antara bonus dengan motivasi kerja karyawan pada PT. Bank Sulselbar Kantor Pusat Makassar.

3. Uji parsial untuk fasilitas $\left(\mathrm{X}_{3}\right)$

Uji hipotesis untuk variabel fasilitas $\left(\mathrm{X}_{3}\right)$ terhadap motivasi kerja karyawan dapat dilakukan dengan dasar pengambilan keputusan sebagai berikut :

d. $\mathrm{H}_{0}: \mathrm{b}_{3}=0$ (tidak ada pengaruh antara $\mathrm{X}_{3}$ terhadap $\mathrm{Y}$ ) $\mathrm{H}_{1}: \mathrm{b}_{3}>0$ (ada pengaruh antara $\mathrm{X}_{3}$ terhadap $\mathrm{Y}$ )

e. Level of convidence $=95 \%$ dengan probability kesalahan $\alpha=0,05$

f. Daerah kritis t tabel $=1,670$ thitung $X_{3}=4,058$

Berdasarkan hasil uji regresi antara fasilitas dengan motivasi kerja karyawan, maka diperoleh nilai t hitung 4,058 $>\mathrm{t}$ tabel $=1,670$. Dan nilai sig $0,000<0,05$ berarti ada pengaruh yang signifikan antara fasilitas dengan motivasi kerja karyawan pada PT. Bank Sulselbar Kantor Pusat Makassar. 
Berdasarkan hasil uji parsial diatas, maka diketahui bahwa variabel bonus yang memiliki pengaruh paling dominan terhadap motivasi kerja karyawan dimana diperoleh $\mathrm{t}$ hitung sebesar 6,379>t tabel sebesar 1,670.

\section{Pembahasan}

Gaji berpengaruh terhadap motivasi kerja karyawan namun gaji tidak berpengaruh secara signifikan terhadap motivasi kerja karyawan. Ini dimungkinkan karena dalam penelitian ini bukan hanya pegawai tetap yang diteliti namun adanya pegawai kontrak yang masih memiliki gaji yang minim. Dan jumlah gaji juga merupakan standarisasi yang berarti sudah ditetapkan sesuai dengan jabatan yang dimiliki. Sehingga menyebabkan gaji berpengaruh namun tidak signifikan terhadap motivasi kerja karyawan. Menurut Hasibuan "Jika balas jasa yang diberikan cukup besar, manajer akan mudah memotivasi bawahannya".

Bonus berpengaruh terhadap motivasi kerja karyawan dan berpengaruh secara signifikan terhadap motivasi kerja karyawan. Dapat dilihat berdasarkan hasil penelitian bahwa bonus merupakan pengaruh yang paling dominan. Karena, dengan adanya bonus yang diterima dapat meningkatkan motivasi kerja karyawan. Dengan adanya pendapatan yang lebih diluar dari gaji yang telah diperoleh. Menurut Sarwoto "Pemberian bonus dapat digunakan sebagai sarana untuk memotivasi karyawan".

Fasilitas berpengaruh terhadap motivasi kerja karyawan dan berpengaruh secara signifikan terhadap motivasi kerja karyawan. Hal tersebut dilihat dari tanggapan responden bahwa dengan adanya fasilitas yang nyaman dalam bekerja maka mereka dapat memiliki motivasi kerja yang tinggi. Dengan begitu karyawan dapat mempermudah dan memperlancar pekerjaannya dengan lingkungan yang nyaman. Menurut Prof. Dr. Hj. Zakiah Daradjat "Fasilitas artinya segala sesuatu yang bisa mempermudah upaya serta memperlancar kerja dalam rangka mencapai suatu tujuan tertentu.

Gaji, bonus, dan fasilitas berpengaruh secara simultan terhadap motivasi kerja karyawan. Hal ini berarti bahwa semakin tinggi gaji, bonus, dan fasilitas yang diberikan maka akan berdampak secara simultan terhadap peningkatan motivasi kerja karyawan pada PT. Bank Sulselbar Kantor Pusat Makassar.

\section{Kesimpulan}

Berdasarkan uraian pembahasan dan hasil penelitian yang telah dikemukakan sebelumnya, maka data tersebut dapat ditarik beberapa kesimpulan sebagai berikut:

1. Variabel gaji mempunyai pengaruh yang positif namun tidak signifikan terhadap motivasi kerja karyawan. Hal tersebut dilihat dari tanggapan responden bahwa masih ada bebarapa responden yang masih belum puas dengan gaji yang didapatkan dan berharap gaji yang diberikan bisa dinaikkan lagi untuk mencukupi kebutuhan mereka sehingga dapat meningkatkan motivasi mereka dalam bekerja.

2. Variabel bonus mempunyai pengaruh yang positif dan signifikan terhadap motivasi kerja karyawan. Hal tersebut dilihat dari tanggapan responden bahwa dengan adanya tambahan bonus yang diberikan mereka dapat memiliki motivasi kerja yang tinggi. Dengan begitu kebutuhan mereka tercukupi dengan adanya tambahan bonus diluar gaji yang telah diberikan.

3. Variabel fasilitas mempunyai pengaruh yang positif dan signifikan terhadap motivasi kerja karyawan. Hal tersebut dilihat dari tanggapan responden bahwa dengan adanya fasilitas yang nyaman dalam bekerja maka mereka dapat memiliki motivasi kerja yang tinggi.

4. Dari hasil pengujian simultan yang telah dilakukan diperoleh hasil yang simultan. Hal ini berarti semakin tinggi gaji, bonus, dan fasilitas maka akan berdampak secara simultan 
terhadap peningkatan motivasi kerja karyawan pada PT. Bank Sulselbar Kantor Pusat Makassar.

\section{Daftar Pustaka}

Handoko T, Hani. 2003. Manajemen. Cetakan Kedelapan Belas. Yogyakarta: BPFE Yogyakarta.

Hasibuan, Malayu S.P. 2002. Manajemen Sumber Daya Manusia. Jakarta: Bumi Aksara. 2007.Organisasi dan Motivasi Dasar Peningkatan Produktivitas. Jakarta: PT. Bumi Aksara.

Kadarisman, M. 2012. Manajemen Kompensasi. Jakarta: Rajawali Pers.

Komaruddin. 1995. Ensiklopedia Manajemen. Jakarta: Bumi Aksara.

Ruky, Achmad S. 2001. Manajemen Penggajian dan Pengupahan Untuk Karyawan Perusahaan. Edisi Pertama. Jakarta: Gramedia Pustaka Utama.

Sarwoto. 1991. Dasar-Dasar Organisasi Manajemen. Jakarta: Ghalia.

Sastrohadisuwiryo, B. Siswanto. 2002. Manajemen Tenaga Kerja Indonesia. Jakarta: Bumi Aksara.

Simamora, Henry. 2004. Manajemen Sumber Daya Manusia. Yogyakarta: SIE YKPN.

Soemarso. 2009. Akuntansi Suatu Pengantar. Edisi Kelima. Jakarta: Penerbit Salemba Empat. Wibowo. 2007. Manajemen Kinerja. Jakarta: PT. Grafindo Persada. 